\title{
Profile of glycopyrronium for once-daily treatment of moderate-to-severe COPD [Corrigendum]
}

Buhl R, Banerji D. Int J Chron Obstruct Pulmon Dis. 2012;7:729-741.

On page 737 in the first paragraph of the "Safety" section, the final sentence "Serious adverse events occurred with a slightly lower frequency in the glycopyrronium treatment group (11\%) compared with placebo (13\%) and the tiotro-

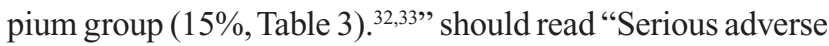
events occurred with a slightly lower frequency in the glycopyrronium treatment group (10\%) compared with placebo $(13 \%)$ and the tiotropium group (15\%, Table 3$).{ }^{32,33}$,
On page 737 in the second paragraph of the "Safety" section, the first sentence "Discontinuations due to adverse events were $10 \%$ in the placebo group and $8 \%$ in the glycopyrronium and tiotropium groups." should read "Discontinuations due to adverse events were $9 \%$ in the placebo group and $7 \%$ in the glycopyrronium and tiotropium groups."

On page 737, Table 3 contains incorrect information. The corrected Table is set out below.

Table 3 Most frequent adverse events ( $\geq 5 \%$ in any treatment group); SAEs occurring in $\geq 5$ patients in any treatment group, deaths, discontinuations due to adverse events and electrocardiographic abnormalities; pooled data from GLOWI and GLOW2. Adapted from D'Urzo A, Ferguson GT, van Noord JA, et al. Efficacy and safety of once-daily NVA237 in patients with moderate-to-severe COPD: the GLOWI trial. Respir Res. 201 I;12:156 32 and Kerwin E, Hébert J, Korenblat P, et al. Efficacy and safety of NVA237 versus placebo and tiotropium in patients with moderate-to-severe COPD over 52 weeks: The GLOW2 study. Eur Respir J. July 26, 2012. ${ }^{33}$

\begin{tabular}{|c|c|c|c|}
\hline & $\begin{array}{l}\text { Glycopyrronium } 50 \mu \mathrm{g} \text { od } \\
(\mathrm{n}=1075)\end{array}$ & $\begin{array}{l}\text { Placebo } \\
(n=535)\end{array}$ & $\begin{array}{l}\text { Tiotropium } 18 \mu \mathrm{g} \text { od } \\
(\mathrm{n}=\mathbf{2 6 7})\end{array}$ \\
\hline Patients with adverse events, $\mathrm{n}(\%)$ & $719(66.9)$ & $379(70.8)$ & $198(74.2)$ \\
\hline COPD worsening & $302(28.1)$ & $189(35.3)$ & $90(33.7)$ \\
\hline Upper respiratory tract infection & $80(7.4)$ & $53(9.9)$ & $30(11.2)$ \\
\hline Nasopharyngitis & $75(7.0)$ & $36(6.7)$ & $21(7.9)$ \\
\hline Sinusitis & $28(5.3)$ & $14(5.2)$ & $10(3.7)$ \\
\hline Patients with SAEs, n (\%) & $112(10.4)^{\mathrm{a}}$ & $67(12.5)$ & $4 I(15.4)^{\mathrm{a}}$ \\
\hline COPD worsening & $28(2.6)$ & $27(5.0)$ & $13(4.9)$ \\
\hline Pneumonia & II (I.0) & $9(1.7)$ & $4(1.5)$ \\
\hline Atrial fibrillation & $7(0.7)$ & 0 & 0 \\
\hline Upper respiratory tract infection, bacterial & $3(0.3)$ & $2(0.4)$ & 0 \\
\hline Deaths, n (\%) & $6(0.6)^{b}$ & $5(0.9)$ & $2(0.7)$ \\
\hline Discontinuation due to adverse event(s) & $74(6.9)$ & $50(9.3)$ & $20(7.5)$ \\
\hline \multicolumn{4}{|l|}{ Electrocardiographic abnormalities } \\
\hline Total notable & $45(4.2)$ & $19(3.6)$ & $14(5.3)$ \\
\hline $\mathrm{QTcF}>500 \mathrm{msec}$ & $2(0.2)$ & $2(0.4)$ & 0 \\
\hline Increase from baseline $30-60 \mathrm{msec}$ & $142(13.2)$ & $60(11.2)$ & $43(16.2)$ \\
\hline Increase from baseline $>60 \mathrm{msec}$ & $7(0.7)$ & $2(0.4)$ & 0 \\
\hline
\end{tabular}

Notes: ancludes patients that had events that occurred during the 30-day follow-up period; bincludes two patients who died during the 30-day follow-up period. Abbreviations: SAEs, serious adverse events; GLOW, GLycopyrronium bromide in COPD airWays; od, once-daily; COPD, chronic obstructive pulmonary disease; QTcF, QT interval with Fridericia's correction; msec, milliseconds.

International Journal of COPD

\section{Publish your work in this journal}

The International Journal of COPD is an international, peer-reviewed journal of therapeutics and pharmacology focusing on concise rapid reporting of clinical studies and reviews in COPD. Special focus is given to the pathophysiological processes underlying the disease, intervention programs, patient focused education, and self management protocols.

\section{Dovepress}

This journal is indexed on PubMed Central, MedLine and CAS. The manuscript management system is completely online and includes a very quick and fair peer-review system, which is all easy to use. Visit http://www.dovepress.com/testimonials.php to read real quotes from published authors. 